\title{
Holmes Rolston, III Can the East Help the West to Value Nature?
}

\author{
Philosophy East and West 37 (1987): 172-190 By permission.
}

\section{EASTERN RELIGION AND WESTERN SCIENCE}

Since the question mixes religion and science, an initial caveat will suggest caution in the subsequent analysis. The Eastern views offered are typically both old and religious. The Western problem is recent and (para)scientific. The West is unsure whether or how far the natural sciences help us to value nature, but in any case the West needs to value nature in the midst of its sciences, notably (1) evolutionary ecoscience, which describes the way biological nature operates, and (2) technological science, which permits humans to prescribe the uses to which nature will be put. Can Eastern religions help the West in its science to value nature?

Western scientists and theologians both know that one ought to mix religion and science with great logical care, a conviction hard won after four centuries of struggle. Religion and science, some say, speak two different languages, and to confuse the two is to make a category mistake, something like confusing the languages of poets and lawyers. For lawyers to write rhymes and for poets to write legal briefs only results in disaster. Christians (at least the more educated among them) have learned not to look to Genesis for science; they look there for the meaning of creation, not for precursors of scientific laws. The steps of the sixday creation do not legislate any order that evolutionary theory must discover, Christians made a category mistake to think that the Biblical passages which recorded that the sun rose and set prescribed Ptolemaic theory and proscribed Copernican theory. Pope Pius XII was fallible when he hoped, on the basis of Genesis, that the big bang theory was true and the steady state theory false

Christians look to the Bible for the meaning of life but find nothing there that sets either an agenda or limits for physics or biology. They take the results of science, where these seem to be established, and then try to put the best interpretation they can on them in the light of their experiences of meaning in the world. The result is sometimes the complementarity, sometimes the independence, and sometimes the conflict of science and religion. But these logical tracks must be carefully specified. Bioscience tells me how my arm goes up. The meaning of this event - that I am waving to my girl-lies in another realm.

What, then, when we take an Eastern turn? After the Western experience, the East will have to wonder whether, to take a Taoist example, it is a category mistake to think that the yang and yin suggest anything for biology or physics. Perhaps Taoists should not prefer oscillating universes over a single universe ever expanding from a once-only big bang. Taoism is little evidence for the binary electronic theory of matter with its opposite and balanced positive and negative

\footnotetext{
Holmes Rolston, III is Professor of Philosophy at Colorado State University, Fort Collins, Colorado. AUTHOR'S NOTE: The author thanks J. Baird Callicott, Donald Crosby, James Boyd, Elliot Deutsch, Roger T. Ames, and Andrew McLaughlin for critical comments, often jumping hard on this springboard far discussion!

Philosophy East and West 37, no. 2 (April 1987). ( $)$ by the University of Hawaii Press. All rights reserved.
} 
charges. The yang/yin does not prescribe any more for science than does the sixday creation. The vital force, $c h ' i$, the principle of harmony, should not lead Taoists to prefer an ecological theory that emphasizes harmony and cooperation and to dislike a theory that is more mechanistic, conflict-prone, or pluralistic, or that (as recent ecological theory has often done) deemphasizes equilibrium.

What we may be getting here are seemingly objective reports of the world that need to be demythologized. These may be subjective reports of meanings construed in the heads and hearts of Taoists, not scientific or prescientific descriptions of ecosystems. What Taoists must do, as must Christians and Jews, is to take the descriptions of science, absent any prescriptions to them, and see whether their experiences accord with these descriptions. If so, well and good; if not, they may want to think further.

Yet the Taoist model does (quite as much as Christians once thought the Genesis account) did seem to describe causal forces in natural history. It seems to offer a model for ecosystems, for evolutionary theory, and even for cosmology. Perhaps the model importantly tells us what subjective reformations humans can undergo, but such experiences would seem to be appropriate for valuing nature only if the subjective reformation is congruent with the valued natural objects.

One possibility is that the Eastern saints were also keen observers of nature and analyzed the way the world works better than did Western scientists, at least until ecology came to the fore. Ecology (it might be thought) is a middle-level science, not a microscience or an astronomical science. One does not need microscopes or telescopes, Geiger counters or ultracentrifuges; one needs to watch successions over decades, the seasons, and the ebb and flow of life at native ranges, and here Taoist descriptions of nature may have anticipated ecology. Perhaps Taoists saw the facts and then valued the facts better than the West; or perhaps the phenomenal facts, better seen, pointed these Orientals to a more adequate metaphysics than any discovered by Occidentals. Taoist religion, then, might prove complementary to ecological science. Taoists may have better discovered the meaning of life in relation to nature, because they had a better prescientific account of operational connections in nature, or vice-versa.

There is, however, a more subtle aspect of the problem. Although the different languages spoken by science and religion are not to be confused, they are not completely insulated from each other. Though science is not metaphysics, it may presume a metaphysics or it may be compatible with some schemes of metaphysics and not others. In this deeper sense, science may not be value-neutral; it may have a loaded metaphysical agenda, and here philosophers and theologians, East and West, can help by clarifying and critiquing the implicit, metaphysically laden assumptions of science.

That is why, for instance, Christians do not always have to take the results of science as canonical. Besides knowing that science routinely changes, they may also find that the sciences arrange to focus on some aspects of experience so as to 
obscure or distort others, as in controversies over free will in behaviorist psychology. They may suspect that a mechanistic metaphysics is being reflected in overly dogmatic claims about how the results of stimulus-response experiments are to be interpreted. Or, in evolutionary theory, they may suspect that the alleged randomness and accident in the evolutionary process is a veil for something that Darwinian theory is not catching because of secularist assumptions, a veil of spiritual processes that Christians did catch at Calvary and continue to detect in ongoing Christian life. Religion cannot suggest the content of any science, but it can notice the forms into which such content is being poured; it can also defend a content of its own and the legitimacy of pouring this into other forms.

So it might be that an Eastern model of nature can critique the metaphysical assumptions in evolutionary ecoscience and in technological science and thereby help the West to value nature. Perhaps an Eastern metaphysics can offer a better model to go with Western science, interpreting that science and making it ethically responsible before its environment. But we cannot presume any such insight. A Taoist ecology might be more muddle than model, like a Christian biochemistry or a Hindu meteorology. We must inquire more particularly whether what the East believed before science helps the West to value nature after science.

East, West, nature, science-all these words are of enormous scope, crammed into a single question. It may prove impossible to generalize, but it may be possible to test some representative answers. One presumption in what follows is that any Eastern help that can be exported West is unlikely to be sectarian, and it will probably lie in the mainstream of Oriental beliefs; also we presume that it is available for export. It is difficult to tear a practice out of the world view in which it is set, and what works in an Eastern climate might not work in Western culture because a particular conduct cannot be sustained without the metaphysics that backs it. The question we address is not whether Easterners can value nature for themselves, but whether they can help Westerners to value nature. Perhaps there is a metaphysics to which the West can be converted, though that seems unlikely. What seems more realistic to expect is that representative Eastern convictions will, in encounter with the West, provoke the West to reassess either its own theory or practice, resulting, for example, in a less anthropocentric framework and in a more sensitive ability to value nature.

The test cases that follow are a springboard for such discussions. (Springboards function well only when jumped on-hard!) These test cases also proceed with a methodology mixing the hard-nosed philosophy of science with that of the gentler discipline of comparative religion. The latter discipline seeks to make the most favorable, sympathetic case for a competing theory, accentuating strengths; the former discipline concentrates on a competing theory's weaknesses and looks at once for falsifications. Both approaches seem important in a search for understanding. 


\section{KARMAN, REINCARNATION, AND BIOLOGICAL VALUE}

Consider the belief in karman and reincarnation, almost omnipresent in Eastern religions. Karman is a doctrine about the persistence of moral value. Such value is experienced to be present paradigmatically in human life, but unsatisfactorily resolved there; therefore, by religious logic, value is exported to other worlds, other generations, and also to nonhuman lives in the biological world. This stretches out morality from personal life and supposes it to be covertly present as a determinant in animal life, so that monkeys or snakes are what they are because of bad karman. Lives are of higher value, as far as individuals go, if they can get themselves reborn and have the possibility by stages of improvement to gain more value (merit, good karman). Serious disvalue is, alas, losing such karman. This belief has powerful meanings since it drives the soteriological quest (at least in the earlier stages) in classical Buddhism and Hinduism. What is its meaning for valuing nature, as this might be exported West? Daisaku Ikeda, a Japanese Buddhist keenly interested in biological conservation, says that karman and reincarnation make all living beings "blood relations," and support with religion the scientific finding that humans have relational links with all forms of life. ${ }^{1}$ The first Buddhist commandment is the injunction to ahimsā noninjury, reverence for life, based on such belief.

This can seem to complement biological values with metaphysical beliefs. Biologists find in Darwinian evolution evidence that we are all blood relations, and if Buddhists and Hindus can gain the belief also from religious sources, so much the better. Reverence for life, although a feeling known by conservation biologists almost universally, is rather hard to derive from pure biology; indeed, evolutionary biology is, in some senses, rather irreverent about life. Natural selection is pushing and hauling, a struggle for life. The survival of the fittest requires the early deaths of most individuals and has resulted in the extinction of ninety-eight percent of all species that have previously existed on earth. If one can derive from Eastern religion an additional reason for reverence for life, so much the more impetus toward biological conservation.

Yet conservation biologists are not really interested in valuing zoological lives metaphysically as once-human lives, transmigrating souls, or karman charges in flux. At least qua biologist, a wildlife biologist's admiring respect for a bull snake cannot be based on the religious belief that it has been or might be reincarnated as someone's grandmother (much less on the belief that he or she might gain good karman by protecting such a soul-incarnating animal). The less biologists hear about a bat or a worm being a reincarnated person the better. Those in the West want to value snakes, bats, and worms as the causal and cybernetic products of natural forces, without projecting onto them unsolved moral problems from human life. Animals need to be valued for what they are intrinsically and for the instrumental roles they play in ecosystems. They need to be valued as biological agents and not as once-upon-a-time moral agents. 
The West needs, for instance, a plausible account of the values lost in extinction and conserved in respeciation, an account of the differences between natural extinction as a normal turnover in evolutionary speciation and anthropogenic extinction without respeciation. We need an account of the seriousness of the loss of biological information in natural kinds, an account of valuing species as this relates to valuing individual organisms. We need to value what we are tempted to call "higher" against "lower" species, and sentient against nonsentient species. According to one reading, karman and reincarnation seem to say that nothing of metaphysical value is ever lost in extinction. Value is only reborn elsewhere. What is the relation between this conservation metaphysic and the conservation of biological value?

The West needs a plausible account of admiring respect for alien life formsjumping spiders and voles, for example. The injunction to ahimsā s initially impressive, involving respect for all forms of life. But when scientists realize that the saints' beliefs about the sorts of beings toward which noninjury is commanded are metaphysically different, they will wonder whether, after Eastern beliefs about spiders and voles are demythologized, disenchanted, and positively biologically informed, the doctrine of ahimsa can remain an effective force to support Western value theory. The West sometimes wants to value these creatures because they are kin to humans, but just as often because they are not. There seems to be something nonanthropocentric about distributing respect for life through all the sentient kinds, and yet when the value distributed there is thought to be karman consequent from moral agency, how do we respect the dimensions of animal life that are nonmoral? Sometimes we want to admire alien experience, or even to admire life that has no sentient experience at all.

Perhaps there is a deeper, esoteric meaning to karman and reincarnation, and the inquiry so far has only examined the popular, exoteric meaning. But before this foundational meaning can be exported West, Eastern interpreters will need to probe how the one level is separable from the other (a demythologizing project?) and how such a metaphysic can help in valuing the organisms that have resulted from speciation in an evolutionary ecosystem. Perhaps this can be accomplished by diagnosing in the West secular metaphysical assumptions that have made us insensitive to religious values present in all living things.

Like an enzyme or catalyst that serves a particular function in the organism in which it evolved but which, serendipitously, can be put to additional beneficial uses by humans who cleverly assimilate it for medical, agricultural, or industrial purposes, there may be something in these Eastern beliefs that can trigger a more functional relationship with nature in the West. But it is not yet clear how this chemistry will work.

\section{BINARY OPPOSITION AND EVOLUTIONARY NATURE}

When the Far East offers counsel to the ecologically distressed West, this is sometimes based on the law of binary opposition, or complementarity, the way 
of the Tao with its oscillating yang and yin. "In Tao the only motion is returning." ${ }^{2}$ Huston Smith, born and bred in China, long the resident religious philosopher at the Massachusetts Institute of Technology, diagnoses how the West has been on a wild "yang trip," evidenced in science and resulting in the ecological crisis, against which "Taoism throws its ounces on the side of yin, but to recover the original wholeness." ${ }^{3}$ The ecological crisis results from too much muscle or machismo; the West needs a recovery of the feminine; we need to flow with nature, properly to attune ourselves to its rhythms in counterpoint. Only then can humans rightly value nature. The Tao that is descriptive of nature becomes prescriptive for human behavior.

There is some risk in discussing a position that begins by affirming that it really cannot be talked about ${ }^{4}$ and goes on to claim that every position contains the seeds of its opposite ${ }^{5}$ (symbolized by the small dark center in the light half, and the light center in the dark half of the Taoist symbol). The model will frequently reverse its tones and be difficult to verbalize in the absence of perceptual experiences that support it. Nevertheless, if this model is exported to challenge conduct in the West, it is going to have to advance some positive claims before Western science and value theory.

Here is metaphysics mixed with ethics, and the science and the religion need to be blended with care. Like accounts of the trinitarian God in the West, accounts of the binary Tao in the East are reports derived from meanings found in life. But just how is bipolar complementarity a description of the nature of nature? How do we move from the is to the ought, to a prescription for human conduct?

(1) What does the model propose to describe? Is the yang/yin a phenomenal model, a model of natural processes resembling what the West would call a causal model? In this case it would seem to operate at the same level as does science, to compete or to be congenial with it, to be testable against science, and vice versa. So far as it says anything that can be talked about, the teaching about the Tao seems to be claiming scientific insight homologous with Newton's laws about the conservation of mass and energy or Darwin's law about the survival of the better adapted. Taoist laws about the succession of yang and yin strikingly endorse discoveries about homeostasis, natural cycles, and equilibriums. The Taoist ecological model predicts yang after yin after yang after yin, ever returning/recycling.

Such paired complementarity can impressively be discovered in the natural world, first at the native ranges at which Taoists in Chinese ecosystems discovered them, and then extrapolated over ranges where science has extended the human powers of observation. There is the oscillation of hot and cold, summer and winter, sun and moon. wet and dry. There are mountains and valleys, the male and the female, the sweet and the sour, growth and decay, waking and sleeping, waxing and waning, life and death. Physicists discover that the world is built with positive and negative charges, that energy and matter interconvert, 
that north poles have their south poles, that particles have their antiparticles, that matter is both wave and particle. Biologists learn how the male/female dichotomy permeates higher plants, cryptogams, and algae, and how genes come in pairs. Meteorologists find warm and cold fronts, and astrophysicists even find that stars wax and wane and wonder whether the universe oscillates: big bang, big squeeze, big bang, big squeeze. Ecosystems especially seem prone to periodic successions, to cycles and rhythms, to returnings. Everything results from the negentropic yang and the entropic yin, dialectically entwined.

(2) Or is the yang/yin a transphenomenal model at a deeper level than that at which science works, perhaps running in a different logical category, a metaphysical model, not an empirical model, one of meanings and not of causes? In this case the findings of science would neither compete with nor confirm it directly. It would rather come into direct confrontation with the Western metaphysics beneath the scientific model. Some excess in a Western metaphysics (the dominion of man), driving the scientific view in both theory and practice (yielding analytic science and technological science), might then be corrected by an Eastern metaphysics (binary complementarity), moderating the arrogance operating in science.

Or does the claim run that what Western science (à la evolutionary ecoscience) is now discovering is really more commensurate with this Eastern binary metaphysics than with the Western metaphysics (the God: man: nature hierarchy) that gave birth to science? The issue, then, is what sort of transphenomenal model (if any is needed at all) is metaphysically adequate to evolutionary ecoscience and to the value questions posed when humans, with the powers of technological science, find themselves threatening the nature out of which they have evolved and in which they must continue to live.

In either case (the parascientific Tao, or the transphenomenal Tao), when a Westerner tries to import this view, there are problems. Employed so extensively, the Tao conflates many things that, outside of the persuasive influence of this paradigm, have no otherwise discoverable connection with each other in nature, none so far as the sciences that are said to be congenial with it have yet revealed. Even restricted to the Chinese categories, male and female have little to do with wet and dry, with mountains and valleys or with eating foods that grow above and below ground. The waxing of youths and the waning of the elderly is a different phenomenon from the sweet and the sour. The near omnipresence of sexuality in biology has nothing to do with the binary electronic theory of matter, and both are something else from succession in ecology. The phenomenal world of science is plural and diverse, and, though there are regularities and underlying structural themes, everything is not that connected to everything else.

The Westerner whose science, with its implicit metaphysics, is challenged by Taoists will be prone to reply in kind: that Taoist teaching is equally a metaphysics filtering what is found to be significant in science, and that the truth may 
as well be that there is no Tao behind all these oscillations. To think that there is a Tao is rather like thinking that the same forces must be showing up throughout astrophysics, microphysics, biochemistry, meteorology, geology, ecology, and economics because equal marks show up so regularly in all the equations used in these sciences. If one chooses a plus-or-minus scale one can do a lot of mapping, but nothing follows about the interpenetrations of organisms and phenomena on all the different sorts of terrain one has mapped. Those who take scientific natural history seriously find genuine emergences of level phenomena that can sometimes be reduced and interrelated, but they may not find that the most adequate key to understanding these storied events, either phenomenally or metaphysically, is some mystic force bonding opposites called the Tao.

Enormously more is going on than is illuminated by binary opposition. There is nothing particularly binary about the atomic table, or quantum theory in general, or excitation levels, or half-life in radioactive decay, or relativity theory; there is nothing particularly binary about the solar system, or Earth's tectonic plates, or black holes, or recurrent glaciation. Likewise with the genetic code, mutation, enzymes, glycolysis, the citric acid cycle, photosynthesis, neurotransmitters, and the evolution of sight, or of learning; and likewise with speciation and extinction, or with the arrival of humans and their cultural histories.

Across all these events, one can, of course, find ups and downs, activity and rest, pluses and minuses, reversibilities and bilateral symmetries; but noticing that orogenesis and erosion characterize geomorphology or that enzymatic chemistries are often reversible does little to provide explanation when one is puzzling over the fact that, while the geological cycles-Precambrian through Pennsylvanian through Recent-repeat themselves, biological events superimposed on these cycles contain great historical novelty. After the complementary opposites are noticed, most of the work of scientific (and metaphysical) explanation still remains to be done, and certainly the valuing of these natural phenomena has not been finished. If the Tao exists, it might, like the laws of thermodynamics, never be violated in nature, but it is also insufficient to explain much about the particular drama of natural history in its large-scale, emergent features.

The West desperately needs an account of evolutionary nature that can explicitly enable its valuation, especially in view of the fact that many scientifically based accounts conclude that nonhuman nature has no value at all. In the big bang there is explosive raw energy, formed at once into particles, formed soon into hydrogen and helium, and formed later into stars, certain of which form heavier elements in the right proportions for life. These stars explode as supernovae; the matter is regathered into planets, with Earth becoming an experiment in life. The fossil stardust, radiated over by solar energy, spontaneously assembles itself into amino acids and preproteins protected in microspheres, and eventually develops into life. Life begins as single cells and, through increasing discoveries of new information that organisms code in DNA, develops into trilobites and 
ultimately into dinosaurs, primates, and persons, all situated in their supporting ecosystems. This process, with its punctuated equilibria, undeterred by punctuated catastrophic extinctions, over geological timespans builds from zero to five million species, from procaryotes to eucaryotes, from taxes and kineses to complex instinctive and learned acts, from objective to subjective life, from matter to mind and even spirit. Then humans look around to value the place they inhabit and the process that has produced them.

From this standpoint, what help does the yang/yin model supply? How does it critique the view reached by the scientific story? The story is one of more out of less, not more of the same, a story of novel emergence, not repetitive oscillations. The ascent from microbes to men, from planets to persons, is not interestingly binary. Or if it is, one has hold only of the subroutines, not of the executive program, if there is one. An ecosystem is in dynamic equilibrium only on a narrow scale of observation; on a wider scale, evolutionary changes are incessant and irreversible. The historical system is becoming what it never before was; it will never again be what it once was. Ecologists are now saying that dynamic equilibrium is less important, even on a narrower scale, than was once thought.

(3) Perhaps the Taoist model is not so much a descriptive claim, scientifically or metaphysically, about the way the universe is operating, as it is a prescription for human conduct. We expect too much when we think that the Taoist model can interpret all of cosmic or even Earth history; the West can only expect that the model might provide some advice for the contemporary present. Its scale of time may be not millennia, but rather decades and centuries. Its scale of magnitude may be not microscopic or astronomical, but middle-range and ecological.

On these scales, balance is appropriate. Any natural population must operate with renewable resources; any cultural population must do likewise. The West has been on its wild yang trip because Americans migrated across an empty continent (so-called) and took a four-century growth trip unprecedented in recorded history. The Europeans, though remaining at home, took a similar growth trip when they extracted resources out of their newly founded colonies. This growth was fueled by, and fueled, Western science, with its metaphysics of exploitation. But all that is over now, as evidenced by the ecological crisis, and the Taoist model is a saner one for a society that has settled into a long-term relation with its surroundings. The West needs to import a stable metaphysics to match the realities of the carrying capacities of the ecosystems that support culture. Operating for many centuries in classical China, Taoists knew the meaning of the life of balance. Their model can be instructive.

But it is difficult to make this advice of Taoism operational in the West, though it functioned well enough in the climate in which it originated. It may be right to say repeatedly "More yin; more yin" in making environmental decisions, but this is a little like saying "More love; more love" in making social decisions. The 
advice is sound enough, but unless one has a more sophisticated model to explain what adding yin or love means in the making of nitty-gritty decisions, and unless one can work the new attitude into either policy regulations or the moral calculus, nothing comes of it. Does wu-wei, inaction, endorse a "hands off" rather than a "hands on" strategy in wilderness management? Is this a warning to geneticists who want to intervene and improve the timber species in our national forests?

The Taoist myth may have contained appropriate recommendations for humans who sought the meaning of life in a rural, medieval culture, but it needs to be demythologized (or remythologized) to test whether it contains contemporary wisdom that can suggest how humans should behave when, through science, they have discovered the extent of historical change, discovered how natural systems actually function, and discovered technological powers to rebuild natural systems. Perhaps the Taoists had worked out details for a life of balance that applied only to bygone Chinese societies, where Taoism was in critical tension with Confucianism. Perhaps the call for more yin is good advice still. A golden mean is always sensible, even though the mean shifts from age to age and from culture to culture. But can this be translated into help in making decisions in the modem, industrialized, high-technology West? Can it teach the West what to preserve, where to compromise, and how much to sacrifice of what remains of the shrinking wilderness?

Perhaps it is too much to expect a high-level ethical maxim, drawn from a metaphysics, to be directly applicable to the problem. It will function more like a symbol or slogan, like "Less is more!" or "Nothing in excess!" and will set a mood or tone with which we approach life in the world, challenging the value matrix of competing maximizers that characterizes so much of the biology, economics, and politics within which Western decisions are made. This maxim can set a matrix of satisfactory balance, counter to the maximizing of consumption. But can the maxim work like this, unless it stays in the ambience of the metaphysics that supports it? Can it show how these metaphysical beliefs trickle down to affect practical decisions? Can it catalyze any action in the West?

\section{NONDUAL UNION AND BIOLOGICAL INTEGRITY}

The West acutely needs an account of individuals in ecosystems, of diverse organisms integrated into a single biotic community, and of plurality in unity, and here an Eastern turn has often seemed promising. No perception is more basic to Eastern convictions than nonduality, as in Advaita Vedānta, or the emptying of all things in a perception of śünyatā, emptiness, in Buddhism. ${ }^{6}$ The Tao is incessant interpenetration, and in Zen every particle of dust contains the universe and engenders all its powers, These accounts vary in details; perhaps some versions are more available for export to the West than others. But it is unlikely that a specifically denominational account can be transplanted to the West; what is more likely is that a generic Eastern metaphysics can encounter and correct a 
mainstream Western view. We can take two such streams from Mahayana Buddhism, one flowing from the Avatamsaka Sütra and, in the section to follow, one in the tradition of the Madhyamikas.

The Avatamsaka Sütra provides a model of the universe in the analogy of a great net, made of precious gems, hanging over Indra's palace. "In each of these gems are found and reflected all the other gems composing the net; therefore, when it is picked up, we see in it not only the entirety of the net but every one of the gems therein." ${ }^{7}$ Alternately, the world is like a candle surrounded on all sides by mirrors, each reflecting the candle and all the other mirrors. Enlightenment brings a sense of close-coupling with the other. That, says D. T. Suzuki, suggests how to solve the ecological puzzle of valuing the individual in community. ${ }^{8}$ It regains the original wholeness, otherwise lost in the fragmented, alienated West. The Avatamsaka Sütra has the answer: all is one; one is all.

A virtue here is that nonduality conquers human arrogance, of which the West has an ample share. The West itself has not lacked for analysts who have found pride to be a fundamental sin, and an old prediction is that "The meek shall inherit the earth." Nevertheless, the West has also thought legitimate an excessive human dominion over nature. Adding a Mahayana insight to the Taoist one explored earlier, the West can discover the interpenetration of all, humans included, in the One. Then the wild yang trip, really an adventure in arrogance, can be steered round to harmony and holism. Contrary to the anthropocentric view, the Avatamsaka view is biocentric.

Or is it? This time we have a metaphor more than a model, and the metaphor may be metaphysics more than science. We have to ask again whether Indra's net is a poetic vision of what the West calls a causal model, to be confirmed or disproved by empirical discoveries in ecosystems. Or do we have a meaning model instead, not necessarily one that can be directly congenial with or challenged by Western science but one that runs parallel in another logical category of explanation? It would then directly confront not science, but metascience, perhaps to alert the West to background assumptions that are constructing the nets with which science fishes. Either way, the metaphor-model does seem to be describing what is going on out there in the world at some level. Either by direct mapping or by an interlevel translation from metaphysics to science, we need to connect the model with operations in ecosystems.

For example, there will be questions about autonomy and conflict, as well as about coaction. An ecologically informed valuer wants a discriminating pluralism that preserves biological integrity at the level of both organisms and systems. Intrinsic value requires that I see the other as other in its differences from me, from humans, and from other lives and objects-even its differences from the Absolute, if an Absolute exists. It requires some looseness and freedom, enough to protect individuality. Systemic value requires an account of things in their niches and roles, specific to local habitats. If everything is equally and intimately, 
but also rather vaguely (nondiscriminatingly), connected to everything else, rising from one fundamental, inarticulate ground, then what are we to make of the differences?

In ecosystems, the diverse connections are to be taken seriously; the differences of kind, species, trophic levels in food pyramids, autotrophs, heterotrophs, and phylogenetic descent are genuine and valuable differences in biological identity and role. Organisms may be quite close-coupled, as are symbionts or members of a breeding population. Or they may be quite loosely coupled or even decoupled. They may be siblings in close identity and competition, or they may inhabit niches so remote from each other that their lives never cross. Divergence is as important as relationship. Orchids are intimately related to their mycorrhizal fungi, but Calypso orchids in the Rocky Mountains have little connection with snow leopards in Tibet. Microbes play essential roles in ecosystems; they can be valued instrumentally; but climbing ferns are so rare that their role is negligible. Can they be valued intrinsically? The West needs help in discriminating Earth's five million species, articulating their connections, appreciating the sorts of relationships they have, and mixing the intrinsic value in organic individuality with the instrumental value of organisms in ecosystems, subsuming if necessary the value of individuals to the value of the community.

At this point a nondual, inarticulate mystic union has got to go further. The candle with the reflecting mirrors is a pretty model, perhaps even a true metaphysics; but it also becomes pretty muddled when a scientist tries to map, or an ethicist tries to value, an ecosystem with it. The central candle (the Absolute) supplies all the light, mirrored round and reflected back equally in all the otherwise empty mirrors, placed at the periphery. Does each mirror have an integrity of its own, with valued differences from the others? Or is each only a reflector? Even the sparkle of the gems in Indra's net is a reflection of borrowed light. How much is intrinsic to each particular gem? Light is reflected from the surface, and the flash and color are to some extent appearances in the eye of the beholder. The gems, too, are hardly more distinguished than mirrors in having individual integrity. Perhaps we should not expect a metaphor to convert to detail in a model; but perhaps the trouble lies not just in the limits of the metaphor but in the flaws in the metaphysics.

The monotheism that (scientists and Easterners may say) has failed in the West has insisted that natural things have an existence derived from God; monotheists also sometimes speak of creatures mirroring the divine image, and they have tried to make the particular creatures into signs of the divine presence. But they have also wanted more than one in all and all in one. Their Yahweh bade Earth to bring forth myriad creatures of itself (that is, speciation) and pronounced each kind to be good intrinsically, endorsing the name and form manifest in each. God substantially and historically recognizes the various kinds. Though the Avatam saka model tempers the anthropocentrism in the monotheist model, one can 
wonder whether too much emptiness, or too much Absolute, has displaced the biological integrity to be found at the multiple loci of the net.

How do we value conflict and struggle in ecosystems? Ecology has arisen within evolutionary theory, where Darwin's nature is in some sense a jungle. The cheetah rips open the gazelle; the gazelle eats the grass; each grass plant competes with its neighbors for nutrients, moisture, and space at the same time that it cross-fertilizes its neighbors in order to reproduce. In ecological succession, the spruce (with Taoist yang?) push out the aspen, and the aspen depend on fires to destroy the spruce (the yin returns!) and regenerate the aspen succession. The trees compete for sunlight and resist insect pests. Plants make allelopathic agents, poisons that inhibit the growth of their neighbors.

Value in a living organism requires the "pushy" defense of individual integrity, which in return requires the destruction and capture of value in other living organisms, the claiming of resources that others might use. Is it going to help to envision this as light from a central source, flashing round gems and mirrors? Is this a competing metaphysics that can help the West to see where it overstates the conflict and competition in nature, and (as ecology has also done) to paint over the Darwinian survival of the fittest a new picture with more interfitting cooperation?

Perhaps here the Mahayanas can fit in the noble truth of suffering, duhkha, and show how everything is driven by thirst, trṣna-except for the fact that, interpreted in such a way, the samsāra cycle is something that Buddhists wish to stop. This world model hardly seems as pretty as Indra's net. Maybe it is only meant to suggest that humans should put a stop to their thirsts (abetted by Western dominance and consumerism) and find a more meaningful life of balance, realizing the interpenetration of all. But not only are humans driven by their thirsts; the ecosystem is driven that way too. The ecosystem is built on injury, value capture, and predation. Does it not go against the grain of such a system for one to preach noninjury, ahimsā ? Inspired by the metaphysics of Indra's net, no one would wish to damage the sparkling harmony in such a world. Perhaps that is the conclusion to which ecology is bringing us: interpenetration past competition, fitness past struggle. Even Darwin once expressed the hope that, as a result of evolutionary theory, humans, animals, and plants "may partake from our origin in one common ancestor" and "may be all netted together," ${ }^{9}$ Indra's net suggests that kind of picture. But we still need to fit into this net some of the rules of Darwin's jungle, where the fittest survive.

Ecologists need to value integrities embedded within niches and defended within ecosystems. They may not need Absolute Truth as much as relative truth. One does not want too deep an ecology too quickly; the "shallow" phenomena are also to be treasured. We sometimes need less eternity and more valuing of the ephemeral. Ecologists, qua ecologists, do not need mystic unity but discriminating plurality in systemic unity, an appreciation for contests in complementarity. 
They need a convincing environmental pluralism with a convincing environmental community, a model by which humans can compare themselves with nonhumans and compare nonhumans with each other, judging each for the intrinsic worth of their ecosystemic roles.

Turning from a descriptive use of Indra's net to prescriptions that might follow from it, a myth of this kind is difficult to translate into action. Four examples can indicate the distance between mystic vision and environmental decision making.

(1) Coloradans need to decide whether to trade water development on the Colorado River, providing growth and convenience for the Front Range cities, against the extinction of the humpback chub, a fish peculiarly evolved with its odd back as a stabilizer in the turbulent spring runoff. The chub cannot live in the lakes behind the dams that humans desire. Some model suggesting how to value human growth and convenience against the unique biological identity of an endangered species would help, but the chub envisioned as a gem in a net sparking equally with humans and with all other kinds of life contributes little to any decision here.

(2) Californians need to decide whether to shoot several thousand feral goats in order to save three endangered plant species-Malacothamnus clementinus, Castilleja grisea, and Delphinium kinkiense - on San Clemente Island, sacrificing several goats for each known surviving plant. It would help to have a value theory that compares sentient life at the goat level—the goats dislocated from their native ecosystem and relocated as misfits in another-against the lives of plants, tokens of their species type, well-adapted to a rare island ecosystem. We seem to place high intrinsic value in the goats along with high negative instrumental value in their misfit location, set opposite the rare intrinsic value and high-quality but low-quantity instrumental value in the plants, which are the last tokens of an irreplaceable type. We have subjective experience in the goats to consider against merely objective life in the plants. To discover in the goats and plants that everything reflects everything else equally only obscures the issue of subjectivity and objectivity in value that we here would like to have explicated. A vision of one in all and all in one is too unsophisticated-or, if you like, too sophisticated - to be of any help.

(3) Florida state and federal authorities need help in resolving their disagreement over whether it is worth spending twenty-seven million dollars to build forty bridges that will allow the nearly extinct Florida panther, a subspecies uniquely adapted to the swamps, to pass under the interstate highway being built across Big Cypress Swamp. The cost of these bridges is about one million dollars per panther. Land acquisition and related costs will bring the total to 112 million-about ten dollars per Floridian and fifty cents per U. S. citizen. It would help to have some account of the worth of panthers, lithe and graceful predators on the top trophic rungs of the swamp ecosystem, versus the cost to citizens. Can 
a Mahāyāna bodhisattva, after meditating on Indra's net, say anything that needs to be weighed seriously by decision-makers?

(4) National park biologists in Wyoming needed help deciding whether to treat an outbreak of pinkeye among the Yellowstone bighorns, having resolved to keep the functioning of the Yellowstone ecosystem as much as possible uninterrupted by human activity. Their decision not to treat the disease resulted in the deaths by blindness, injury, and starvation of two hundred bighorns, or half the herd. That coincided with a flourishing of the Chlamydia microbe and resulted as well in a high golden eagle population, which feasted on the carcasses. Thus it would help to have a value theory that trades the worth of uninterrupted natural systems against the preventable suffering of wild sheep. Inspired by the vision of Indra's net, does one do nothing (following also the Taoist wu-wei, or practice noninjury, ahims $\bar{a}$, on the sheep or the microbes, or cultivate a sense of nonduality with the interpenetrating whole?

To value nature, we need both horizontal and vertical accounts. The horizontal account describes and values the natural kinds, the phenomena, in relation to each other. This will mix the descriptions of science with an axiology appropriate to empirical things. The vertical account connects and evaluates the phenomena in terms of a noumenal Ground. This will be metaphysics, not science. Indra's net seems to provide a horizontal (scientific, empirical, phenomenal) model simultaneously with a vertical (noumenal, metaphysical) model. But until they are further developed, the connections are rather nondiscriminating.

It is perhaps a category mistake here to confuse the informing vision with a practical decision; this is like confounding again what poets and lawyers do. The vision is poetry; citizen and agency decision-making is the legal nitty-gritty. Dōgen at Eiheiji would not drink a full dipper of water from the mountain stream, but poured halfback into the stream, rejoicing in the river's onward flow. That is Zen poetry, and the West cannot expect to derive water law in Colorado from it, stipulating minimum stream flow for endangered fish species. It can only produce a reverence for the stream; and water law will follow. It can only define a value matrix; it cannot plot particular values on that matrix.

Yet if we have no translation scheme between these categories, the heavenly poetry is of no earthly use. We do not fault the religious depth of vision because it lacks empirical information that the biosciences can supply, but we do expect it to function as a diagnostic symbol. When such empirical information is supplied, and when value questions arise in result, we are dismayed when the vision is too nondiscriminating to be operational. A metaphysics can hardly be expected to provide a blueprint for action, but if a metaphysics cannot orient action in some meaningful way, then it is of no help where the West needs help—valuing the environment that humans inhabit. Such a theory cannot be put into practice environmentally, though perhaps it can be put into practice in other waysexistentially or soteriologically. 


\section{NIRVĀNA, EMPTINESS, AND EXTINCTION}

At least it can be said that the Avatamsaka Sütra affirms things-all things equally like gems in a net—and errs on the side of excessive affirmation. Nothing is despised, however lowly it might be; the bodhisattvas vow to enlighten the last blade of grass. Phenomenal things are intimately identified with the divine. All is one; one is all.

But such excessive affirmation is not always the case. When the Eastern depth evaluation does come, there sometimes is a tendency to extinguish the phenomena-a threat of extinction (to pose the issue in provocative terms) about which any would-be borrowers of such an evaluation in the West will have some uneasiness. We can notice the etymological alliance of nirvāna ("going out") with extinction, to open the issue, ${ }^{10}$ and turn to Mādhyamika Buddhism as a representative case. Additional troublesome and related words are śūnyā, empty, and súnyatā, Emptiness.

These are metaphysical words, used with great deference; Mādhyamika sometimes says that it makes no claims at all with them, at least no conceptual claims that can be separated from perceptual experience. Silence is what is most appropriate. Still, if anything is to be available for export, something about nature is going to have to be said with these words. And, metaphysical terms though they are, they do seem to be applied to the phenomena. Samsāra as well as nirvāna , is said to be śünyā, empty. Some characteristics (for example, trṣnna, thirst, or duhkha, suffering) that drive samsāra will be extinguished in nirvāna . Precisely what gets extinguished? How does this involve the valuing of nature?

Nāgārjuna, the founding figure in Mādhyamika Buddhism, hopes for the great "quiescence of plurality" in Emptiness. ${ }^{11}$ With the "cessation of phenomenal development," samsāra is seen to be nirvāna ${ }^{12}$ "That state which is the rushing in and out of existence when dependent or conditioned - this state, when not dependent or not conditioned, is seen to be nirvāna. ${ }^{\text {"13 }}$ "There ... nothing moves, neither hither nor thither." ${ }^{14}$ Candrakīrti, Nāgārjuna's disciple, tells us that in nirvāna there will be "no existence, no ego, no living creature, no individual soul, no personality, no Lord." "There is in it no individual life whatever." ${ }^{15}$ Such description suggests that phenomena face a perilous brush with extinction at the noumenal level.

This description of nirvāna affects the valuation of phenomena. Unredeemed, this world is "a mirage, a magical illusion, a dream, a mock show, an airy castle in the sky, a bubble on the water, a passing stir in the wind." ${ }^{16}$ The world is "a disease, a boil, a thorn, a misfortune."17 "In antagonism to the entire world is the enlightenment of the Tathagatas," ${ }^{18}$ Candrakīrti says that after the Buddha has "hit the absolute reality," Buddha exclaims, "There is here in this world neither reality, nor absence of illusion. It is surreptitious reality, it is cancelled reality, it is a lie, a childish babble, an illusion!"19 Candrakīrti praises the beauty of Mādhyamika: "It saves us from the misery and from phenomenal existence 
altogether," "There is in this plurality not the slightest bit of what is absolutely real, ... nothing at all to justify the claim that a phenomenal reality has been established by us. ${ }^{20}$

There is some positive truth in such valuation; the phenomena are not absolutely real, and, treated as an object of craving, the world reliably yields misfortune. The Mādhyamikas' śūnyatāy here may be psychologically necessary to achieve certain personal transformations for which they strive. But, taken logically as claims about nature, neither are the phenomena absolutely surreptitious; we in the West want positively to establish phenomenal existence, not to cancel it. We want the world redeemed, to speak religiously; or, better, we want humans to be redeemed in their world. Perhaps Mādhyamika Buddhism can help the West to value nature, challenging the West to repent from its aggrandizing attitude; perhaps the West can help Mādhyamika Buddhism to revalue nature, challenging it to repent for an excessive devaluing of nature.

A principal Buddhist scholar in the West, Edward Conze, after a lifetime of studying the Mādhyamika texts, concluded: "The teachings of the Prajñāpāramitā have little significance for the present age. To be quite truthful, they are equally irrelevant to any other age. They are meant for people who have withdrawn from society. ... Leaving worldlings to get on with their worldly problems, these Sūtras assume that the whole sense-linked, or conditioned, world is unsatisfactory, and that preoccupation with it is unworthy of our true mission in life." ${ }^{21}$ That does not sound promising for a search for help in an environmental crisis, which is, after all, a worldly problem.

Perhaps there is paradox here: some dialectic between emptiness and fullness, so that one must extinguish the world to regain it; some analog to the losing of life in order to gain it of which Jesus speaks, a death and resurrection of the world. It has often seemed to outsiders that Calvinist teachings about predestination should logically lead to paralysis in the world. If God foreordains every event, what place has human effort? But, to the contrary, insiders found the teaching invigorating and went hard to work building a better world, bringing in the Kingdom of God. Outsiders may think that Mādhyamika Buddhism devalues the phenomena in emptiness; insiders find, to the contrary, that it rightly revalues the phenomena. Then they can go to work conserving nature. But truth that works by paradox is going to be difficult to export to the West.

Mādhyamika's total extinction of phenomenal existence is only one of many Buddhist moods, only an early part of a bigger truth, and even Mādhyamika Buddhism promises, with penetration on the far side of śünya , to give samsāra as nirvāna, to give back the phenomena. "There is nothing whatever which differentiates the existence-in-flux ( samsāra) from nirvāna; ... There is not the slightest bit of difference between these two." ${ }^{22}$ What this means, if it means anything statable to those with no vision of śunya , is going to be difficult to export.

Buddhism knows how desire drives not only ecosystems but human life, and 
Buddhism can chasten and contain human desire. It is often said that when Buddhism moved to China and Japan it underwent a this-worldly transformation. Zen Buddhists insist that the mountains return as mountains after one has seen their emptiness. Their haiku will give us glad hearts before nature-frogs, violets, snow, the autumn moon. The yang and yin of the Tao can be superimposed on the emptiness of śs̄nyatā. Chinese and Japanese artists, religiously inspired, sometimes developed great aesthetic sensitivities toward nature. So there is evidence that Buddhism sometimes knows how, by way of the reciprocal interpenetration of the absolute Buddha-world and the world of individual phenomena, to give an inclusive unity to all things without robbing each individual of its own special meaning in the universe.

In the same century that the West has come to need help in valuing nature, so seriously that it considers importing Eastern religious thought, the East has often sought help and imported Western science and technology. The East now faces on its own soil the task of applying its religions to these sciences for an effective valuing of nature. Assuming that a theory should apply (be operational) and bear fruit in at least this sense, a test of the power of Eastern thought will be to see how environmental problems are resolved in industrialized Eastern nations-Japan or Taiwan for example.

An even more critical test case will be to study events in Hawaii- a critical case environmentally and a crossroads of East and West. An island ecosystem fragile, possessing many endemic species, and of great beauty. Hawaii is a bellwether state for environmental concern. Of sixty-eight species of birds unique to the Hawaiian Islands, forty-one are now extinct or virtually extinct. Of endemic plants, 250 are already extinct and half the remaining 2,200 species are endangered or threatened. More bird, animal, and plant species have become extinct in Hawaii than in all of North America. Domesticated animals - cattle, goats, pigs-have played havoc with the native flora, and deforestation and development have seldom been planned so as protect the fauna. What have Eastern influences in Hawaii been able to contribute to the solutions of these problems? What might they contribute?

The West awaits arguments and creative solutions that, without requiring a conversion to Buddhism, Taoism, or Hinduism, it can borrow and use as catalysts to illuminate the complexities of evolutionary ecoscience, to criticize its own valuations of nature, and to make decisions before the environmental tradeoffs it faces. My own judgment is that the East needs considerable reformulation of its sources before it can preach much to the West.

NOTES

1. Aurelio Peccei and Daisaku Ikeda, Before It Is Too Late (Tokyo: Kodansha International Limited, 1984), p. 65.

2. Tao Te Ching, stanza 40, from Arthur Waley, trans., The Way and its Power (London: George Allen and Unwin, 1934, 1965). 
3. Huston Smith, "Tao Now," in Ian Barbour, ed., Earth Might Be Fair (Englewood Cliffs, New Jersey: Prentice-Hall, 1972), pp. 62-81; citation on p. 80.

4. Tao Te Ching, stanza 1.

5. Ibid, stanzas $9,14$.

6. There is a Buddhist account of sünya in which no claims are made. Sünyatā is not some Absolute, but absolute silence. But if Buddhists are silent and make no claims, it is hard to see how they can offer a metaphysics, or a practice based on silence, that can help the West to value nature in environmental affairs.

7. D. T. Suzuki in the introduction to B. L. Suzuki, Mahāyāna Buddhism, 2d ed. (London: David Marlowe Ltd., 1948), p. xxxii.

8. Ibid. See also "The Role of Nature in Zen Buddhism," in D. T. Suzuki, Zen Buddhism (Garden City, New York: Doubleday and Co., 1956), pp. 229-258.

9. Charles Darwin, in Darwin: A Norton Critical Edition, ed. Philip Appleman (New York: W. W. Norton Co., 1970, 1979), p. 78.

10. The same root appears in nirguna Brahman, and the inquiry pressed against the Mãdhyamikas could be, mutatis mutandis, pressed against Advaita Vedāntists. Sankiara delights in the (1) "homogeneity of Brahman," the One without a second and prays for (2) "the total eradication of worldly existence." Phenomenal things perish in Brahman, and (3) "nobody who knows their worthlessness will hanker after them." (4) "There is no good to be attained by the knowledge of the narrative of the creation." (5) "Those whose ideal is the attainment of the highest good do not entertain any respect for creation in its diversity because it can lead to no purpose." These citations are from (1) The Bṛhadäranyaka Upanişad with the Commentary of Sankkarāchärya, trans. Swāmi Mādhavānanda (Calcutta: Advaita Ashrama, 1934, 1965), 5-1-1; (2) Commentary on the Isä Upanişad, 7, in Eight Upanişads with the Commentary of Śankaräcärya, trans. Swami Gambhirananda, 2 vols. (Calcutta: Advaita Ashrama, 1959, 1972), vol. 1, p. 14; (3) Commentary on the Katha Upanisad, 1-1-28, in Eight Upanişads, vol. 1, p. 122; (4) Commentary on the Aitareya Upanisad, 2-1, trans. R. P. Singh, in The Vedānta of Śankara, a Metaphysics of Value (Jaipur: Bharat Publishing House, 1949), p. 277; and (5) Commentary on the Mändụikya Upanișad, 1-7, trans. Singh.

11. Nāgärjuna, Müla-Mädhyamika-Kärikäs, Fundamentals of the Middle Way, trans. Th. Stcherbatsky, in The Conception of Buddhist Nirväna (The Hague: Mouton, 1965), chapter 25, verse 24 (pp. 78, 208).

12. Nāgārjuna, Müla-Mādhyamika-Kärikäs, chapter 25 , verse 24 , trans. Frederick J. Streng, in Emptiness: A Study in Religious Meaning (Nashville, Tennessee: Abingdon Press, 1967), p. 217.

13. Nāgärjuna, Müla-Mädhyamika-Kärikäs, chapter 25, verse 9, in Streng, Emptiness, p. 216.

14. Nāgärjuna, "Dedication" to Müla-Mädhyamika-Kärikās, in Stcherbatsky, Conception, p. 69.

15. Candrakīrti, Commentary on the Müla-Mädhyamika-Kärikäs, trans. Stcherbatsky, p. 127, p. 182.

16. The Large Sütra on Perfect Wisdom (Mahā-Prajñā-Päramitā-Sütra), trans. Edward Conze (Berkeley, California: University of California Press, 1975), pp. 141, 193, 305, 634-636.

17. Ibid., p. 204.

18. Ibid., p. 376.

19. Candrakirti, Commentary, in Stcherbatsky, p. 125.

20. Ibid., p. 84, p. 111.

21. Edward Conze, Selected Sayings from the Perfection of Wisdom, trans. Edward Conze (London: The Buddhist Society, 1955), pp. 16-17.

22. Nägärjuna, Müla-Mädhyamika-Kärikäs, chap. 25, verses 19-20, in Streng, Emptiness, p. 217. 